\title{
A new procedure to adapt any type of soil for the consolidation and construction of earthen structures: projected earth system
}

\author{
R. Fuentes-García, I. Valverde-Palacios $\bowtie$, I. Valverde-Espinosa \\ Technical Upper School of Architecture, University of Granada (Granada, Spain) \\ هnachoval@ugr.es
}

\author{
Received 2 October 2014 \\ Accepted 16 March 2015 \\ Available on line 22 J uly 2015
}

\begin{abstract}
The "projected earth system" is put forward as an alternative construction method. The soil from each site is adapted following a specific protocol to make it suitable for spraying. The type of construction and the receiving surface determine the machinery and spraying system used (dry or wet mix). The result will be similar in texture and colour to the original material (in the case of earth walls) or to the surrounding material.
\end{abstract}

KEYWORDS: Mortar; Lime; Carbonation; Fibre reinforcement; Mechanical properties

Citation/Citar como: Fuentes-García, R.; Valverde-Palacios, I.; Valverde-Espinosa, I. (2015) A new procedure to adapt any type of soil for the consolidation and construction of earthen structures: projected earth system. Mater. Construcc. 65 [319], e063. http://dx.doi.org/10.3989/mc.2015.06614.

RESUMEN: Un procedimiento nuevo para adaptar cualquier tipo de suelo para la construcción y consolidación de estructuras de tierra: Sistema de Tierra Proyectada. Se plantea la "tierra proyectada" como nuevo sistema constructivo. Se adecuará la tierra de cada intervención con un protocolo para poder ser proyectada. El tipo de intervención y el soporte sobre el que se proyectará determinarán la maquinaria y el sistema de proyección (vía seca o húmeda). El resultado tendrá similar textura y color que el soporte restaurado (en muros de tierra) o que el material del entorno (en taludes carreteros u obras de tierra de nueva construcción).

PALABRAS CLAVE: Mortero; Cal; Carbonatación; Refuerzo de fibras; Propiedades mecánicas

Copyright: (c) 2015 CSIC. This is an open-access article distributed under the terms of the Creative Commons Attribution-Non Commercial (by-nc) Spain 3.0 License.

\section{INTRODUCTION}

Earth is an integral part of sustainable architecture (1) in the context of both restoration and new construction. We present the methodology used to adapt soil to the same projection systems currently used with other construction materials, hence the name: "projected earth" (patented).

Most research and advances in the use of earthbased construction materials has focussed on strengthening adobe as a material, or on the study of compressed stabilized earth blocks (CSEB) (2-5), which in Spain is the only existing standard governing earthen building materials (6). There are few standards governing rammed earth construction (7): Zimbabwe introduced the SAZS 724 standard (8) and in India the IS 2110 standard (9) applies to soilcement walls.

The most important advances in rammed earth construction using the "tapial" technique have centred on increasing the density and loadbearing capacity of the earth either by improving the 
compaction process by replacing earth rammers with small mechanical compactors (in the case of new buildings), or by using hardeners, selecting specific kinds of materials and reinforcing them with natural or artificial fibres (10-11). In the context of restoration, attention is focussed on in situ consolidation of such materials (12), based on the fact that clay-rich soils encountered while building roads or digging foundations must be stabilised and/or consolidated to prevent problems caused by changes in humidity. The material most widely used for this purpose has always been lime.

Other products can also be used to consolidate soils, such as asphalt emulsion, polyvinyl acetate, cellulose, polyvinyl alcohol, plaster, polyacrylamide, rubber emulsions, different types of organic resin and cement-based grout (13-15). These products are not always suitable due to the wide variety of textures found in different rammed earth structures or to the poor solubility of $\mathrm{Ca}(\mathrm{OH})_{2}(16)$. However, geopolymer binders can be an effective alternative for consolidating earth-based architectural structures, while Izaguirre et al. (17) managed to improve the properties of lime mortars by adding natural polymers (commercial starch).

Most earthwork restoration projects have involved the use of standard lime or cement mortars. These, however, do not bind with the underlying material for a variety of reasons: chemical and mineral incompatibilities, poor permeability, which results in the formation of vapour barriers, or poor adherence, mainly due to the method of application. Other factors can also be involved, such as shrinkage, formation of surface salts, or the use of bonding agents that are stronger (18) than the receiving surface.

At other times, the project requires modern techniques such as micropiling (19) instead of consolidation. This approach enables the earthen element to remain where it was discovered and form an integral part of the new construction.

We therefore propose the Projected Earth System as an alternative application technique, replacing cement or lime mortar with the same earth used in the original construction, albeit prepared according to a protocol. This would guarantee compatibility with the receiving surface and produce an earth-based mortar with the physical, chemical and mechanical properties needed to ensure stability over time.

Before the "Projected Earth" technique was patented in 2005, the only products available for this technique were gunite, shotcrete, at times with added pigments, and more recently earthen plaster.

The main objective of this project is to adapt any kind of soil for use in projection techniques by means of the protocol described here, which has so far given excellent results. We also recommend the best spraying systems (wet or dry mix) and machinery based on the type of project and construction.

\section{MATERIALS AND METHODS}

\subsection{Materials used}

Base Material (BM). The material used in this project was Alhambra Formation (20), which is composed of sand, gravel, and pebbles in a reddish loamy clay matrix. This accounts for $90 \%$ of the dry ingredients. This Formation is used in many of the surviving rammed earth constructions in the city of Granada (Spain), including fortifications, dwellings and walls. Table 1 a shows the physical and chemical parameters of the BM obtained from tests described in the UNE standard (21-30). Table 1 b shows the physical and mechanical parameters obtained

TABLE 1. Typical physic-chemical (1a) and physic-mechanical parameters (1b) of the BM

\begin{tabular}{|c|c|c|c|c|c|c|c|c|c|c|}
\hline \multicolumn{11}{|c|}{ Physic-chemical parameters (1a) } \\
\hline $\begin{array}{l}\text { Maximum } \\
\text { size }(\mathrm{mm})\end{array}$ & $\begin{array}{c}\text { Sand } \\
\text { equivalent } \\
\text { test }\end{array}$ & $\begin{array}{c}\text { Sieve } \\
\text { module }\end{array}$ & $\begin{array}{c}\text { Classification } \\
\text { on Casagrande } \\
\text { chart }\end{array}$ & $\begin{array}{c}\text { USCS } \\
\text { classification }\end{array}$ & $\begin{array}{c}\text { Lambe } \\
\text { test }\end{array}$ & $\begin{array}{l}\text { Shrinkage } \\
\text { limit test }\end{array}$ & $\begin{array}{c}\text { Carbonate } \\
\text { content } \\
(\%)\end{array}$ & $\begin{array}{c}\text { Soluble } \\
\text { sulphates } \\
\text { content }(\%)\end{array}$ & $\begin{array}{c}\text { Organic } \\
\text { matter } \\
\text { content }(\%)\end{array}$ & $\begin{array}{c}\text { Water } \\
\text { content } \\
(\%)\end{array}$ \\
\hline \multirow{4}{*}{$20-40$} & \multirow{4}{*}{$22-34$} & \multirow{4}{*}{$4.61-2.79$} & & GC & Low expansivity & \multirow{4}{*}{$>15 \%$} & \multirow{4}{*}{$13.5-17.1$} & \multirow{4}{*}{0} & \multirow{4}{*}{0} & \multirow{4}{*}{$0.57-0.62$} \\
\hline & & & CL & $\mathrm{SC}$ & Not critical & & & & & \\
\hline & & & CL-ML & SC-SM & $<0.8 \mathrm{~K} \mathrm{~g} / \mathrm{cm}^{2}$ & & & & & \\
\hline & & & & GC-GM & & & & & & \\
\hline
\end{tabular}

\begin{tabular}{|c|c|c|c|c|c|c|c|c|c|}
\hline \multicolumn{10}{|c|}{ Physic-mechanical parameters (1b) } \\
\hline \multirow[b]{2}{*}{$\begin{array}{l}\text { Specific } \\
\text { gravity } \mathrm{g} / \mathrm{cm}^{3}\end{array}$} & \multirow[b]{2}{*}{$\begin{array}{l}\text { "in situ" dry } \\
\text { density } \mathrm{g} / \mathrm{cm}^{3}\end{array}$} & \multirow[b]{2}{*}{$\begin{array}{c}\text { "in situ" } \\
\text { wet bulk } \\
\text { density } \mathrm{g} / \mathrm{cm}^{3}\end{array}$} & \multicolumn{4}{|c|}{ Standard Proctor } & \multicolumn{3}{|c|}{ Standard Proctor } \\
\hline & & & $\begin{array}{c}\text { Optimal } \\
\text { humidity } \\
(\%)\end{array}$ & $\begin{array}{c}\text { Maximum } \\
\text { density } \\
\text { g/cm }\end{array}$ & $\begin{array}{c}\text { Void } \\
\text { ratio "e" }\end{array}$ & $\begin{array}{c}\text { Degree of } \\
\text { saturation } \\
(\%)\end{array}$ & $\begin{array}{c}\text { Optimal } \\
\text { humidity } \\
(\%)\end{array}$ & $\begin{array}{c}\text { Maximum } \\
\text { density } \\
{\mathrm{g} / \mathrm{cm}^{3}}^{3}\end{array}$ & $\begin{array}{c}\text { Compressive } \\
\text { strength } \\
\mathrm{MPa}\end{array}$ \\
\hline 2.6 & $1.7-1.75$ & $1.8-2.0$ & $9.5-11.0$ & $2.0-2.06$ & $0.28-0.31$ & $30-33$ & 10 & 2.06 & 3.7 \\
\hline
\end{tabular}




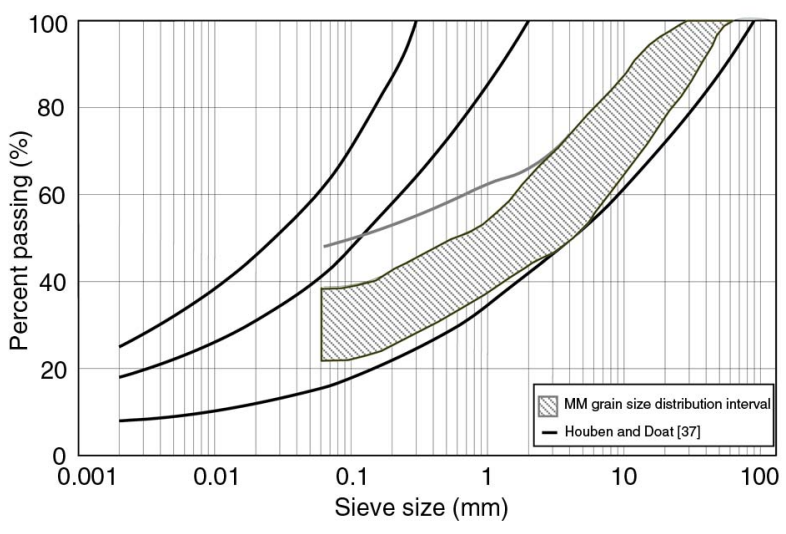

Figure 1. BM and Houben and Doat (37) grading envelope.

through the UNE-EN standard (31), articles and books (32-34) and the UNE standard (35-36).

Figure 1 shows the granulometric characteristics of the BM and Houben and Doat's (37) grading envelope for soil used in rammed earth constructions $(<20 \%$ clay and $>45 \%$ sand). Our BM soil meets these requirements, at least up to silt size $(0.06 \mathrm{~mm})$.

The BM is very heterogeneous in texture, a factor that affects not only the coarse but also the fine fraction, silt and clay, which comprise between $22 \%$ to $38 \%$ of the soil, although this does not affect the suitability of the material, as shown in the grading envelope in Figure 1.

Under X-ray diffraction crystallography, at $<50 \mu$ the soil is mainly composed of phyllosilicates, calcite, dolomite, portlandite and quartz. In terms of mechanical properties, BM has a Standard Proctor (SP) density of $2.06 \mathrm{~g} / \mathrm{cm}^{3}$ (35) and a simple compressive strength (36) of $\sim 3.7 \mathrm{MPa}$ (using PS-type samples with typical optimal humidity of $10 \%$ ).

Hydrated lime. CL90-S content is $8 \%$ of soil weight (38).

White builder's cement (BL22.5X (39)): in this case, content is $2 \%$ of soil weight. This binder gives the sprayed BM initial mechanical strength without obstructing air permeability. The aim is not to obtain greater initial adherence to the receiving surface, since this is achieved by the projection pressure and is sufficient to ensure short-term durability.

Additives (40): two types of additives have been used. The first is a superplasticiser to reduce the amount of water needed for spraying. This is a versatile, colourless, high performance additive usually added to cement to increase fluidity without the need for additional water, thereby avoiding shrinkage and loss of mechanical strength. Secondly, after projection, a water repellent is applied to the earth to improve durability. This additive does not waterproof the surface of the sprayed earth, since this would affect transpiration.

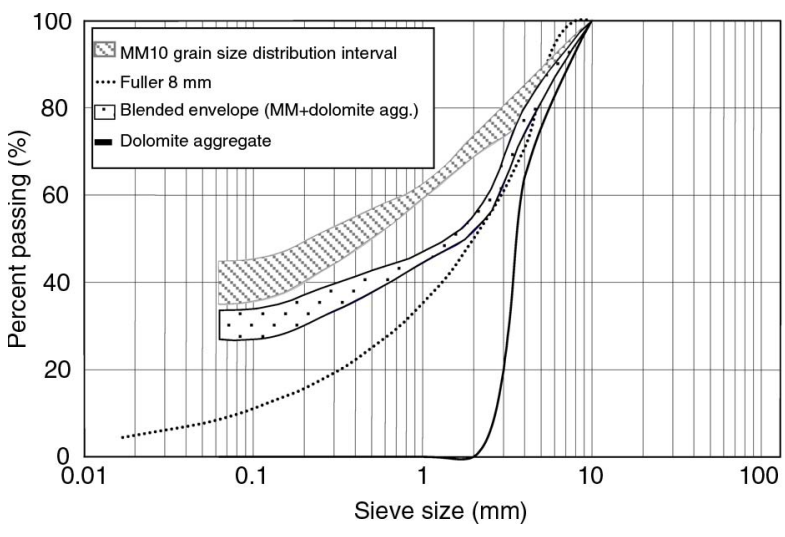

FIgURE 2. BM grading envelope (tmax 10), MM+dolomite aggregate grading envelope, Fuller's ideal grading curve (tmax 8$)$ and dolomite aggregate grading curve.

The water used meets standard EHE-08 (41) specifications for the manufacture of cement.

Aggregate: this material is needed to improve the gradation of mixtures in which the base material contains over $30 \%$ of fines (clay and clayeysilt), to bring this proportion down to $20-25 \%$. The aggregate is white in order to blend in with the structure, and must meet all EHE-08 (41) requirements, or other standards in place worldwide. The aggregate should be limestone or non-reactive silica, although other types can also be used provided they are laboratory-tested to ensure suitability. In the case reported here, $25 \%$ of the BM was replaced by 4-8 $\mathrm{mm}$ dolomite aggregate.

When a graph is plotted with aggregate particle size, Fuller's ideal grading curve (42) maximum size, Tmax 8, the BM grading envelope (tmax 10) and the resulting $\mathrm{BM}+$ aggregate mixture curve for this size, it can be seen that the 4-8 aggregate fraction reduces the deviation from Fuller's ideal curve until the mixture curve almost matches the latter up to $2 \mathrm{~mm}$ sieve size and also significantly reduces the $<2 \mathrm{~mm}$ particle content. This means that less water is needed to achieve PS density, which remains within approximately the same range (Figure 2).

\subsection{Methodology}

The flow chart in Figure 3 shows both the field and laboratory methodology followed in this study.

\subsubsection{Field study and laboratory soil characterisation tests}

These allowed us to select a suitable BM collection site, which in turn involved examination of the earth structure to be restored, determining its most 


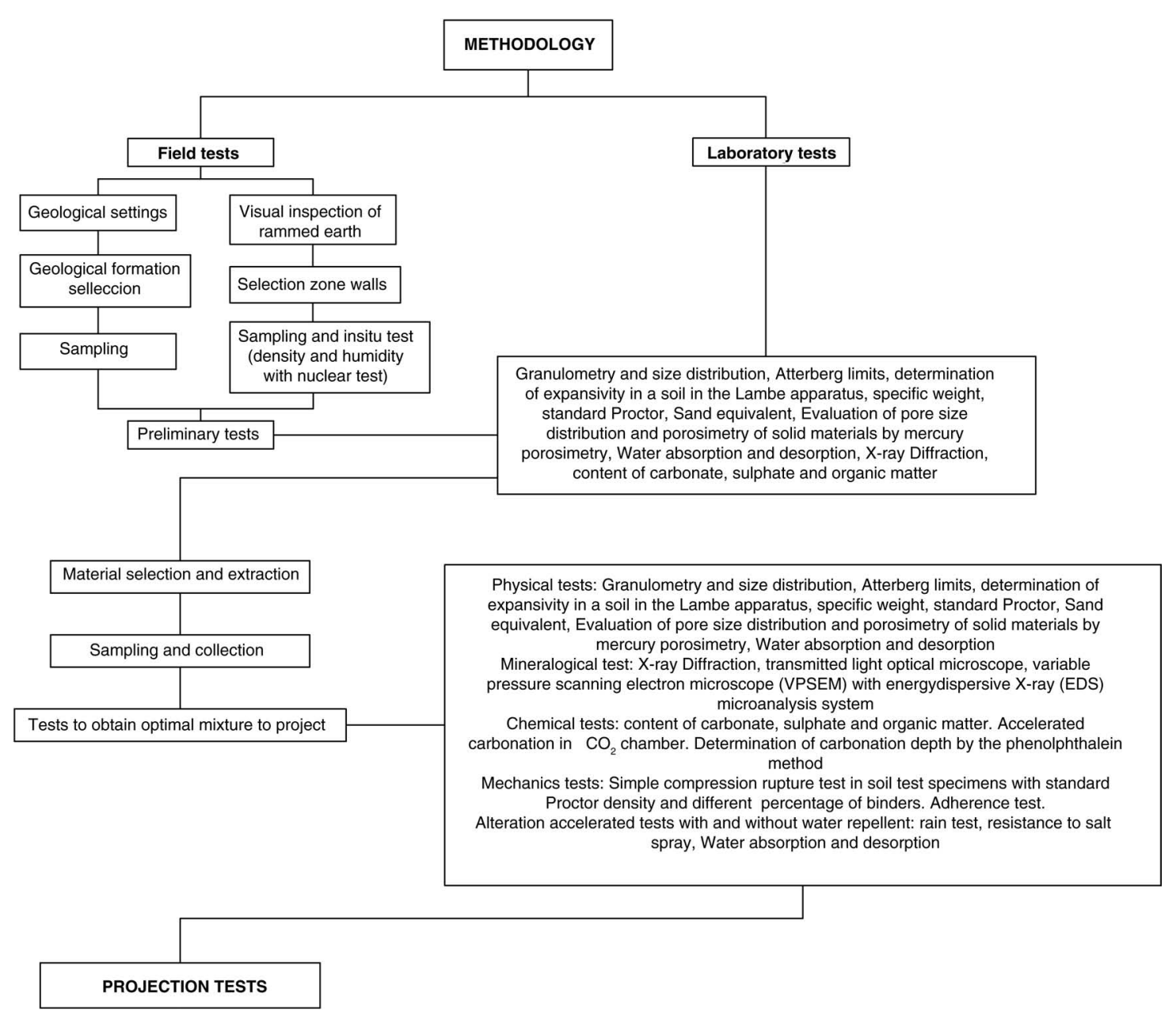

FIGURE 3. Field and laboratory methodology.

important properties in order to subsequently compare them to the BM soil chosen to ensure that it was the most suitable.

In the case of roadside embankments, however, the material removed during construction will be analysed for suitability.

In all cases, the soil used for the mixture should be the same as that used in the original structure, which calls for preliminary field tests together with laboratory tests to characterise the soil (Figure 3).

\subsubsection{Adapting the earth to the requirements of the projected earth system}

Since the soil will ultimately be sprayed onto the structure, particles greater that $10 \mathrm{~mm}$ were removed from the BM to prevent damage to the pumps and rebound, consistent with the requirements of standard UNE 83-607-94 (43) for projected cement and mortar, size 0-8 mm. After a search of the literature, we chose the BASF grading envelope for sprayed concrete (Degussa grading envelope) (44), Figure 4.
Figure 4 shows how adjustment of the maximum particle size increases the percentage of fines in the silt fraction. This causes the important deviation that, however, starts at sizes under $0.5 \mathrm{~mm}$. The $\mathrm{BM}$ is closer to the BASF (44) envelope because it uses finer particles than those required by standard UNE 83-607-94 (43).

It should be noted that the larger the maximum particle size, the greater the rebound rate, while fines can lead to shrinkage. The BM does not match cement or mortar projection standards due to: (i) a high percentage of fines (between $4 \%$ and $9 \%$ of fines are needed for sprayed concrete (42)); (ii) too few sand equivalents and low fineness modulus values; however, it does comply with the recommended maximum size of $8-10 \mathrm{~mm}$ due to the limitations imposed by the pumping equipment, which in turn minimises rebound. The greatest problem lies in the excess of fines, the quantity of which, however, cannot be reduced since they act as a colouring agent to allow the new earth to blend in with the tone of the structure under restoration, 


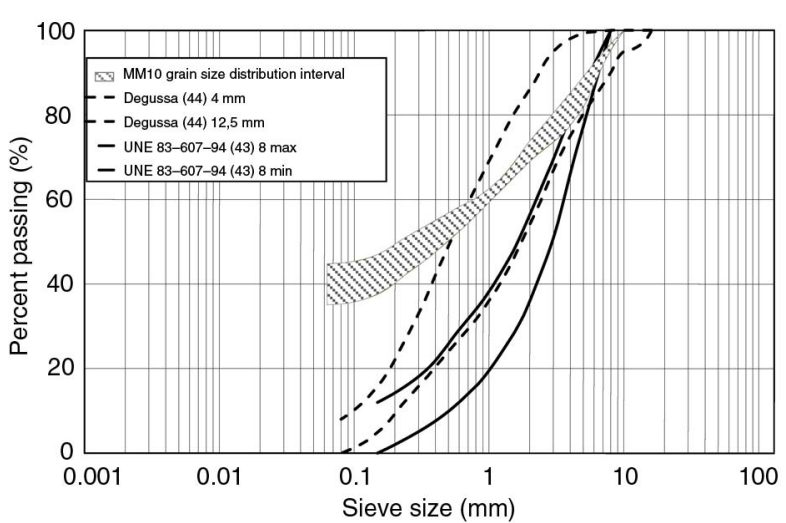

Figure 4. BM, UNE 83-607-94 (43) and Degussa (44) grading envelopes.

which evidently calls for the addition of higher doses of superplasticisers.

It is sometimes advisable to add white aggregate 4-8. This would help reduce shrinkage of sprayed, hardened earth and also reduce the percentage of fines, if needed $(>35 \%)(42)$.

\subsubsection{Spraying protocol}

Several different mixtures were used for physical, mineralogy, mechanical, durability and chemical testing, including a natural and forced carbonation study using different percentages of lime. On the basis of these tests the two most suitable blends (D1 and D2) were chosen, differentiated by the substitution of $25 \%$ of BM for aggregate.

Blends D1 and D2 were then tested on different spraying guns in order to chose the best equipment (45).

- Piston pump gun for dry mix (DM). Used for sprayed cement and granite.

- Piston pump gun for dry mix (WM). Used for sprayed cement and granite.

- Worm drive gun for wet mix (WMW). Used for sprayed mortar, particularly in building.

In all case similar formwork was used: $1.40 \mathrm{~m}^{2}$ sheets of chipboard coated on the inside with a threecentimetre layer of $\mathrm{BM}$, attached using a suitable adhesive.

\section{RESULTS AND DISCUSSION}

\subsection{Adapting the material}

A predominantly sandy soil with a certain amount of gravel, grit and fines with low to medium plasticity (22-24) (CL and CL-ML) was used, including around $22 \%-38 \%$ of $<0.063 \mathrm{~mm}$ fraction. Such variations are to be expected when working with this type of granular geological formations classified under the Unified System of Soil Classification (46) as GC, SC, SC-SM and GC-GM. In the case of other formations, given the good results obtained when sprayed, suitable corrections should be made to adjust the mixture to the grading envelopes obtained here, which are in turn very close to those recommended by Houben and Doat (37).

Authors such as Rodríguez Ortíz (47) recommend the use of low expansion potential soils to prevent the appearance of shrinkage fissures in the sprayed earth. Our BM meets this specification; using the Lambe Determination of Expansivity in a Soil test, potential expansion should be "not critical" (25).

The density and compressive strength parameters were based on corresponding values obtained in existing walls built in Granada using this type of material and rammed earth techniques (dry density between $1.7-1.75 \mathrm{~g} / \mathrm{cm}^{3}$ and wet density between $1.8-2.0 \mathrm{~g} / \mathrm{cm}^{3}$; the real density of the soil should be around $2.6 \mathrm{~g} / \mathrm{cm}^{3}$ ). These parameters have been shown to be particularly durable even after several hundred years.

Using SP energy, density increases significantly with respect to the tamping foot compaction technique, with a dry bulk density [1] of around $2.0 \mathrm{~g} / \mathrm{cm}^{3}$ and a wet density (with around 6\% humidity) [2] of around $2.2 \mathrm{~g} / \mathrm{cm}^{3}$; logically, real density $(\mathrm{G})$ is the same as indicated above, and compressive strength tested on oven-dried samples is around 3.5 MPa. The MP test was not included in the protocol because the densities and strength obtained after spraying only approach SP values.

$$
\begin{aligned}
& \gamma_{d}=\frac{G}{1+e} \\
& \gamma_{d}(1+W)
\end{aligned}
$$

These values are associated with an "e" void [3] ratio of $<0.3(<0.4)$. This, together with dry bulk density $\left(>1.85 \mathrm{~g} / \mathrm{cm}^{3}\right)$, among other parameters, allowed us to assign the SP compaction a "very dense" relative compaction value (33). With regard to the "S $\mathrm{S}_{\mathrm{r}}$ " saturation level [4], our level of $52 \%$ was acceptable since it allowed us to achieve SP density without sacrificing air permeability in compacted soil. The $S_{r}$ values are consistent with the fact that the void ratio continues to decrease as compaction energy, and therefore density, increases, which is solely due to the air being expelled or compressed and dissolved in the water. This would not have been the case if the $\mathrm{S}_{\mathrm{r}}$ value of the SP had been above $80 \%-85 \%$, since air permeability is greatly reduced (34). These $S_{r}$ values and void ratio show that even greater densities could be achieved by increasing compaction energy even above modified proctor (MP) levels. It is safe to say, therefore, that the process, at least in the case of these soils, does not end with MP energy. 


$$
\begin{gathered}
e=\frac{n}{1-n} \\
S_{r}=\frac{W}{W_{\text {sat }}}
\end{gathered}
$$

To define the best blend using dolomite aggregate, different lime and cement dosages were studied in detail, and forced carbonation was tested in a $\mathrm{CO}_{2}$ chamber. All tests were conducted using the same protocol and samples manufactured with SP energy (Table 2).

In summary, Table 3 shows the most important physical and mechanical parameters considered in samples manufactured using different blends both before and after spraying. The first are manufacturing using SP energy and the second by extracting $5 \mathrm{~cm}$ cores using a diamond bit cement sampler (48).

\subsection{Spraying Method}

Several spray tests were needed to determine the best system (dry or wet mix) and spray gun according to the type and scope of the restoration or construction project.

The dry mix system is not recommended, since this causes significant segregation as the mixture is projected from the nozzle. When the mixture was sprayed, a large quantity of aggregate was separated from the soil by the pressure of the compressed air, and subsequently lost; it was impossible to determine the exact aggregate content of the sprayed mixture. We also noted a slight delay between projection of the dry mass and the water, making it impossible to control the volume of water added and to add a water reducing agent (superplasticiser).

The wet mix spray gun, meanwhile, had several advantages, including control of (i) added water, (ii) superplasticiser, (iii) and binders. This gave an evenly blended, dense and strong spray mixture while reducing rebound and poor adhesion.

Samples were taken of the sprayed mixture from different guns: DM, WM and WMW and the density and compressive strength were compared with the same results from the SP compaction tests using the same dosages (Table 4).

The mechanical strength of the mixture sprayed from the smallest gun (WMW), once totally dry, ranges from 3.8 to $4.2 \mathrm{MPa}$. This will increase over time due to the effect of natural carbonation. In the case of spray guns typically used in civil engineering works (WM), strength ranges from 4.3 to 4.8 $\mathrm{MPa}$.

Spray tests were also crucial in establishing the order in which the ingredients are added to the

TABLE 2. Determination of dry density and compressive strength in samples with different

\begin{tabular}{|c|c|c|c|c|}
\hline & $\begin{array}{l}\text { Simple compressive } \\
\text { strength (MPa) }\end{array}$ & $\begin{array}{c}\text { Water } \\
\text { content }(\%)\end{array}$ & $\begin{array}{l}\text { Dry density } \\
\left(\mathrm{g} / \mathrm{cm}^{3}\right)\end{array}$ & $\begin{array}{l}\text { Phenolphthalein carbonation } \\
\text { (diameter of non-carbonated } \\
\text { region from the core of the sample) }\end{array}$ \\
\hline Lime-free BM & 3.7 & 10.4 & 2.06 & - \\
\hline $4 \%$ lime, no $\mathrm{CO}_{2}$ chamber & 4.6 & 10.9 & 1.98 & Not carbonated \\
\hline $4 \%$ lime, 7 d. $\mathrm{CO}_{2}$ & 5.8 & 10.9 & 1.99 & $2.0 \mathrm{~cm}$ \\
\hline $4 \%$ lime, $14 \mathrm{~d} . \mathrm{CO}_{2}$ & 4.5 & 10.9 & 1.98 & total \\
\hline $4 \%$ lime, $28 \mathrm{~d} . \mathrm{CO}_{2}$ & 4.1 & 10.9 & 1.98 & total \\
\hline Lime-free BM & 3.7 & 10.4 & 2.06 & - \\
\hline $8 \%$ lime & 3.3 & 12.7 & 1.89 & Not carbonated \\
\hline $8 \%$ lime, $7 \mathrm{~d} . \mathrm{CO}_{2}$ & 4.2 & 12.7 & 1.9 & $3 \mathrm{~cm}$ \\
\hline $8 \%$ lime, $14 \mathrm{~d} . \mathrm{CO}_{2}$ & 4.1 & 12.7 & 1.9 & total \\
\hline $8 \%$ lime, $28 \mathrm{~d} . \mathrm{CO}_{2}$ & 4.5 & 12.7 & 1.9 & total \\
\hline Lime-free BM & 3.7 & 10.4 & 2.06 & - \\
\hline $15 \%$ lime & 2.4 & 14.3 & 1.83 & Not carbonated \\
\hline $15 \%$ lime, 7 d. $\mathrm{CO}_{2}$ & 2.3 & 14.3 & 1.7 & $5 \mathrm{~cm}$ \\
\hline $15 \%$ lime, $14 \mathrm{~d} . \mathrm{CO}_{2}$ & 3.4 & 14.3 & 1.8 & $4 \mathrm{~cm}$ \\
\hline $15 \%$ lime, $28 \mathrm{~d} . \mathrm{CO}_{2}$ & 4.1 & 14.3 & 1.80 & $1.5 \mathrm{~cm}$ \\
\hline Lime-free BM & 3.7 & 10.4 & 2.06 & - \\
\hline $20 \%$ lime & 1.9 & 15.1 & 1.81 & Not carbonated \\
\hline $20 \%$ lime, $7 \mathrm{~d} . \mathrm{CO}_{2}$ & 2.4 & 15.1 & 1.7 & $5 \mathrm{~cm}$ \\
\hline $20 \%$ lime, $14 \mathrm{~d} . \mathrm{CO}_{2}$ & 3.6 & 15.1 & 1.7 & $3.5 \mathrm{~cm}$ \\
\hline $20 \%$ lime, $28 \mathrm{~d} . \mathrm{CO}_{2}$ & 4.6 & 15.1 & 1.80 & $1.5 \mathrm{~cm}$ \\
\hline
\end{tabular}
lime percentage and time (days) of forced carbonation in a $\mathrm{CO}_{2}$ chamber 
TABLE 3. Densities and compressive strength

\begin{tabular}{|c|c|c|}
\hline Sample characteristics & $\begin{array}{l}\text { Density } \\
\left(\mathrm{g} / \mathrm{cm}^{3}\right)\end{array}$ & $\begin{array}{c}\text { Compressive } \\
\text { strength (MPa) }\end{array}$ \\
\hline $\mathrm{BM}(\mathrm{SP})$ & 2.06 & 3.7 \\
\hline $\mathrm{BM}+8 \%$ lime (no forced carbonation) (manufactured using SP energy) & 1.89 & 3.2 \\
\hline $\begin{array}{l}\mathrm{BM}+8 \% \text { lime (almost wholly carbonated after } 7 \text { days in carbonation chamber) (manufactured using SP } \\
\text { energy) }\end{array}$ & 1.89 & 4.2 \\
\hline $\mathrm{BM}+8 \%$ lime $+2 \%$ cement (manufactured using SP energy) (breakage at 28 days) & 1.9 & 7.0 \\
\hline $\mathrm{BM}+8 \%$ lime $+2 \%$ cement $+25 \%$ dolomite aggregate (manufactured using SP energy) (breakage at 28 days) & 2.02 & 7.1 \\
\hline Sample taken one year after spraying with $\mathrm{BM}+8 \%$ cal & 1.48 & 2.7 \\
\hline \multirow[t]{3}{*}{ Sample taken two months after spraying with $\mathrm{BM}+8 \%$ lime $+2 \%$ cement 22.5} & 1.64 & 4.9 \\
\hline & 1.93 & 4.3 \\
\hline & 1.85 & 3.8 \\
\hline \multirow[t]{2}{*}{ Sample taken one year after spraying with $\mathrm{BM}+25 \%$ dolomite aggregate $+8 \%$ lime $+2 \%$ cement 22.5} & 1.98 & 4.8 \\
\hline & 1.87 & 4.2 \\
\hline \multirow{2}{*}{$\begin{array}{l}\text { Restoration of a rammed earth structure using projected earth with the formula } \mathrm{BM}+25 \% \text { dolomite } \\
\text { aggregate }+8 \% \text { lime }+2 \% \text { cement } 22.5 \text { (sample taken two years after spraying). }\end{array}$} & 1.83 & 3.4 \\
\hline & 2.02 & 3.8 \\
\hline
\end{tabular}

TABle 4. Density/Strength of projected earth samples

\begin{tabular}{lccccccc}
\hline & \multicolumn{2}{c}{ Soil samples manufactured using SP energy } & & \multicolumn{2}{c}{ Samples taken after the sprayed } \\
\cline { 2 - 3 } \cline { 6 - 7 } & $\begin{array}{c}\text { Maximum } \\
\text { density (g/cm }\end{array}$ & $\begin{array}{c}\text { Optimal } \\
\text { humidity (\%) }\end{array}$ & $\begin{array}{c}\mathbf{2 8} \text { days Compressive } \\
\text { strength (MPa) }\end{array}$ & $\begin{array}{c}\text { Maximum } \\
\text { density (g/cm }{ }^{3} \text { ) }\end{array}$ & $\begin{array}{c}\text { 28 days Compressive } \\
\text { strength (MPa) }\end{array}$ \\
\hline D1VH & 1.9 & 12.4 & 7.02 & & 1.93 & 4.36 \\
D2VH & 2.02 & 10.1 & 7.07 & & 1.98 & 4.87 \\
D1VHTS & 1.9 & 12.4 & 7.02 & & 1.85 & 3.86 \\
D2VHTS & 2.02 & 10.1 & 7.07 & & 1.87 & 4.23 \\
\hline
\end{tabular}

mixture, since Projected Earth does not behave in the same way as other mortars mixed before spraying. Based on the test results, the following was determined to be the best order: first, all the water content, then all the cement + lime, half the soil, half the superplasticiser, half the soil and finally half the superplasticiser. If anti-shrinkage agents are used, these should be added at the end of the foregoing stages.

Figure 5 shows the density and strength of the earth samples plotted on Houben's (15) graph for other earth-based construction systems. It can be seen that density and strength are similar to that of rammed earth walls, which has from the outset been one of the aims of this project.

Figure 6 shows the practical application of the protocol described in this manuscript. In this case, projected earth was used to restore a rammed earth wall built using the calicastrado technique, in which a layer of lime slurry is applied between each block of earth. Seven years later, we can safely attest to the excellent durability of the restoration, even without the application of a layer of water-repellent. The soil used was the same as that used in the original construction, ensuring compatibility in terms of texture and colour.

\section{APPLICATIONS}

This projected earth technique has three possible applications: 1. Restoration of earthen structures. In this case it can be used to coat the structure or to compensate for lost material. 2. As an alternative building material in the context of sustainable architecture. 3 . As a means of protecting previously stabilised roadway embankments and adapting them to the surroundings (restoration). This would prevent damage from years of erosion and would greatly benefit the environment by reducing the visual impact of such constructions.

\section{CONCLUSIONS}

The same earth as the original structure is always used to give the sprayed earth the same physical, chemical and mechanical properties as the receiving structure and ensuring it is consistent in terms of colour and texture. When spraying projected earth 


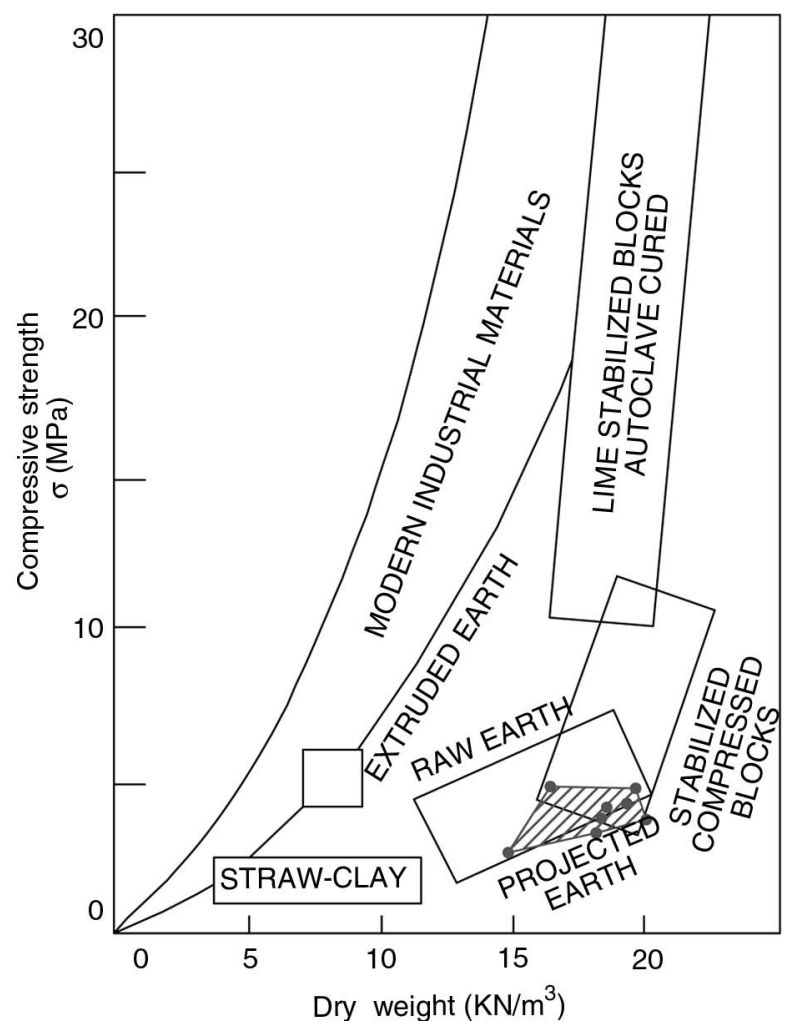

FIGURE 5. Projected earth in Houben's graph of other earth-based construction systems. on to a damaged rammed earth structure, earth from the surroundings should be used to ensure it is similar to that used in the original construction. In the a new earth building, earth should be taken from a nearby site to ensure the colour and texture of the finished building is compatible with the surroundings.

Projected earth is an effective method of repairing damage using material with the same texture and colour while meeting acceptable standards of density and strength and ensuring excellent adherence to the receiving surface.

In the absence of official standards for this technique, we hope this test protocol will help adapt other soils for use with sprayed mortar techniques.

We propose this BM soil as a standard. Grading envelopes should be adjusted to the particle sizes put forward here, and SP-type samples should be tested in the laboratory to ensure they have $40 \%$ more compressive strength than that required by the finished, sprayed earth mortar.

It is important to bear in mind that the mixing order outlined here is unique to projected earth, and is not similar to that used in any other material. The volume of water added should be adjusted to account for the humidity of the source soil (25). First, add all the water, then the cement-lime mixture, half the soil, half the superplasticiser (40), half the soil and finally half the superplasticiser. If anti-shrinkage

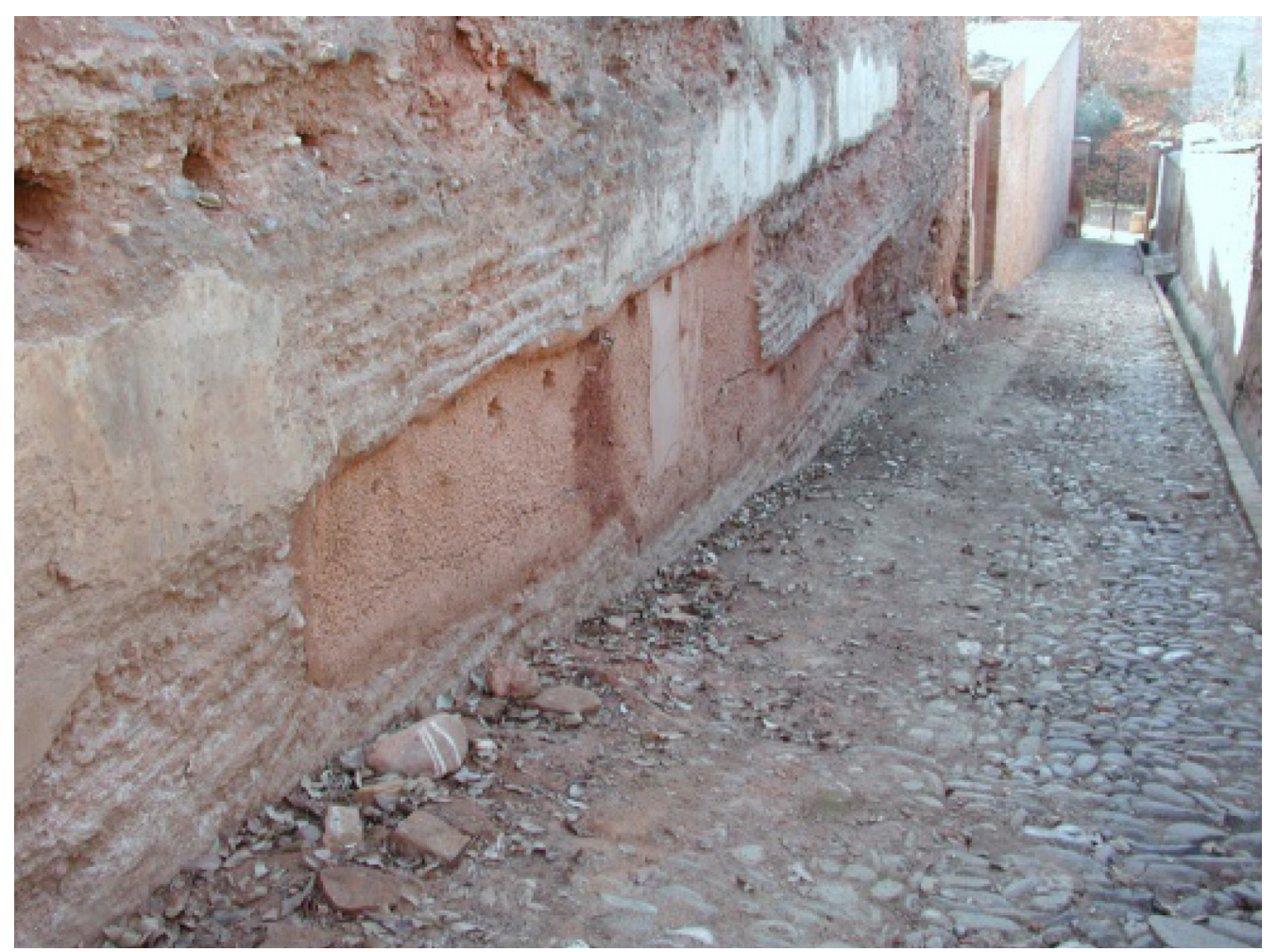

FIGURE 6. Restoration of a rammed earth wall with significant loss of mass at the base. 
agents are used, these should be added at the end of the foregoing stages.

For reasons of performance and projection pressure, piston pump guns (mainly used in civil engineering projects) should not be used in the restoration of rammed earth structures, although they are suitable for restoration of roadway embankments or other surfaces that can withstand such pressure.

During the restoration or building process, antishrinkage materials should be used, such a glass or organic fibre or dramix-type steel fibre, although the latter are not suitable for worm drive guns since they cause obstructions in the nozzle. Mesh made of plastic or other materials can also be sandwiched between layers or projected earth.

Durability was tested by means of accelerated ageing, water resistance, rain resistance, ice and salt spray tests; based on the results obtained, we recommend applying a water repellent to the finished surface.

\section{ACKNOWLEDGEMENTS}

We would like to thank the staff of SITE S.A. (Granada, Spain) for their help in this study, and also the Department of Building Construction of Granada University.

\section{REFERENCES}

1. Valverde-Palacios, I.; Fuentes, R.; Valverde-Espinosa, I.; Martín Morales, M.; Del Moral Ávila, C.; Delgado Méndez, L.; Santos, J.; Canals Peres, E. (2012) Projected earth system. Aplicación de esta técnica a la construcción de viviendas sostenibles y ecológicas: ECODOME. XI Congreso Internacional de Rehabilitación del Patrimonio Arquitectónico y Edificación, 556-564.

2. Yetgin, S.; Cavdar, Ö.; Cavdar, A. (2008) The effects of the fiber contents on the mechanic properties of the adobes. Constr. Build. Mater. 22, 222-227. http://dx.doi.org/10.1016/j. conbuildmat.2006.08.022.

3. Degirmenci, N. (2008) The using of waste phosphogypsum and natural gypsum in adobe stabilization. Constr. Build. Mater. 22, 1220-1224. http://dx.doi.org/10.1016/j. conbuildmat.2007.01.027.

4. Cid-Falceto, J.; Mazarrón, Fernando R.; Cañas, I. (2012) Assessment of compressed earth blocks made in Spain: International durability tests. Constr. Build. Mater. 37, 738-745. http://dx.doi.org/10.1016/j.conbuildmat.2012.08.019.

5. Silveira, D.; Varum, H.; Costa, A.; Martins, Tiago, Pereira, H.; Almeida, J. (2012) Mechanical properties of adobe bricks in ancient constructions. Constr. Build. Mater. 28, 36-44. http://dx.doi.org/10.1016/j.conbuildmat.2011.08.046.

6. UNE 41410 (2008). Bloques de tierra comprimida para muros y tabiques. Definiciones, especificaciones y métodos de ensayo. AENOR, 28.

7. Cid, J.; Mazarrón, I.; Cañas, I. (2011) Las normativas de construcción con tierra en el mundo. Inf. Constr. 63 [523], 159-169. http://dx.doi.org/10.3989/ic.10.011.

8. SAZS 724 (2001) Standard Code of Practice for Rammed Earth Structures. Harare. Standards Association of Zimbabwe.

9. IS 2110 (1981) Code of Practice for in situ construction of Walls in buildings with soil-cement. Bureau of Indian Standards, 15

10. Bestraten, S.; Hormías, E.; Altemir, A. (2011) Construcción con tierra en el siglo XXI. Inf. Constr. 63 [523], 5-20. http:// dx.doi.org/10.3989/ic.10.046.
11. Galán-Marín, C.; Rivera-Gómez, C.; Petric, J. (2010) Claybased composite stabilized with natural polymer and fibre. Constr. Build. Mater. 24, 1462-1468. http://dx.doi.org/10.1016/ j.conbuildmat.2010.01.008.

12. Palumbo, G.; Ginell, W.S.; Rodríguez-Navarro, C. (1999) Earthen architecture research survey: Analysis report. Getty Conservation Institute. Los Angeles.

13. Armbrust, D.V.; Dickerson, J.D. (1971) Temporary wind erosion control: cost and effectiveness of 34 commercial materials. J. Soil Water Conserv. 26, 154-157.

14. Chiari, G. (1990) Chemical surface treatments and capping technique of earthen structures: a long-term evaluation. $6^{\text {th }}$ International Conference on the Conservation of Earthen Architecture: Adobe 90 Preprints. 267-273. Las Cruces, New Mexico, USA.

15. Houben, H.; Guillaud, H. (1994) Earth Construction: a comprehensive guide. Intermediate Technology Publications, London.

16. Elert, K.; Sebastián, E.; Valverde I.; Rodríguez-Navarro, C. (2008) Alkaline treatment of clay minerals from the Alhambra Formation: Implications for the conservation of earthen architecture. Appl. Clay Sci. 39, 122-132. http://dx.doi. org/10.1016/j.clay.2007.05.003.

17. Izaguirre, A.; Lanas, J.; Álvarez, J.I. (2011) Effect of a biodegradable natural polymer on the properties of hardened lime based mortars. Mater. Construcc. 61 [302], 257-274. http://dx.doi.org/10.3989/mc.2010.56009.

18. Espuga, J. (ed.); Berasategui, D.; Gibert, V. (1999) Revoques y estucados. Teoría y práctica. Barcelona. Ediciones de la Universitat Politécnica de Catalunya, SL, Barcelona, 133.

19. Valverde, I.; Fuentes, R.; Valverde-Espinosa, I.; Martín Morales, M.; Santos-Sánchez, J. (2014) El recalce con micropilotes para la conservación de un muro de tierra compactada realizado con fábrica del Tapial. Inf. Constr. 66 [534]. http:// dx.doi.org/10.3989/ic.12.131.

20. Ontiveros Ortega, E. (1995) Estudio de los materiales empleados en la construcción de los tapiales de las Murallas de Granada. Tesis Doctoral. Universidad de Granada, 303.

21. UNE 103101 (1995) Determinación granulométrico de suelos por tamizado. AENOR, 15 .

22. UNE 103109 (1995) Método de ensayo para Determinar el índice equivalente de arena de un suelo. AENOR, 8.

23. UNE 103103 (1994) Determinación del límite líquido de un suelo por el método del aparato de Casagrande. AENOR, 10.

24. UNE 103104 (1993) Determinación del Límite Plástico de un suelo. AENOR, 2.

25. UNE 103600 (1996) Determinación de la expansividad de un suelo en el aparato Lambe. AENOR, 10.

26. UNE 103108 (1996) Determinación de las características de retracción de un suelo. AENOR, 14.

27. UNE 103200 (1993) Determinación del contenido de carbonatos en los suelos. AENOR, 6 .

28. UNE 103202 (1995) Determinación cualitativa del contenido en sulfatos solubles de un suelo. AENOR, 4.

29. UNE 103204 (1993) Determinación del contenido de materia orgánica oxidable de un suelo por el método del permanganato potásico. AENOR, 4.

30. UNE 103300 (1993) Determinación de la humedad de un suelo mediante secado en estufa. AENOR, 4.

31. UNE EN 1097-7:2009 (2009) Determinación de la densidad real del filler. Método del picnómetro. AENOR, 14.

32. Valverde-Palacios, I.; Chacón, J.; Valverde-Espinosa, I.; Irigaray, C. (2012) Foundation models in seismic areas: Four case studies near the city of Granada (Spain). Engineering Geology, 131-132, 57-69. http://dx.doi.org/10.1016/j.enggeo. 2012.02.004

33. González de Vallejo, L.I. (Coordinador) (2005) Ingeniería Geológica, 25-27, 57. Ed. Pearson Educación, S.A., Madrid, 695.

34. Arredondo, F.; Giménez, F.; Jiménez, J.A.; Llamazares, O.; De Navacerrada, G.; Sendin, M. (1977) Compactación de terrenos. Terraplenes y pedraplenes. Teoría y práctica. 11-13, Editores técnicos asociados, S.A., Barcelona, 261.

35. UNE 103500 (1994) Ensayo de Compactación Proctor Normal. AENOR, 6. 
36. UNE 103400 (1993) Ensayo de rotura a Compresión Simple en probetas de suelo. AENOR, 8 .

37. Houben, H.; Doat, P. (1982) Construir en tierra. Francia. Ed. CRAterre, Grenoble.

38. UNE EN 459-1 (2011) Cales para la construcción. Parte 1: Definiciones, especificaciones y criterios de conformidad. AENOR, 50

39. RC-08 (2008) Instrucción para la recepción de cementos. Boletín Oficial del Estado, n¹48. RD 956/2008. España, 47.

40. SIKA. (2013) Prontuario, 69, volumen1/2, Madrid, 858.

41. EHE-08 (2008) Instrucción de Hormigón estructural. Comisión Permanente del Hormigón. Ministerio de Fomento, 702.

42. Fuentes-García, R.M. (2010) Construcciones de tierra. El tapial. Nuevo sistema para construcción y restauración mediante la técnica de "Tierra Proyectada". Tesis Doctoral. Universidad de Granada, 390.

43. UNE 83607 (1994) Morteros y hormigones proyectados. AENOR, 40 .
44. BASF Construction. Tecnología BASF aplicada al hormigón proyectado. The chemical Company. Chemicals España, S.L. Admixture Systems. http:/www.basf-cc.es.

45. Valverde, I.; Fuentes, R.; Valverde, I. (2010) Adecuación de la tierra para ser puesta en obra mediante la técnica de proyección. Tierra proyectada. En Arquitectura construida en tierra, tradición e innovación. Congresos de Arquitectura de Tierra en Cuenca de Campos 2004/2009 (245-254). Cátedra Juan de Villanueva. Universidad de Valladolid.

46. ASTM D2487-11 (2011) Standard Practice for Classification of Soils for Engineering Purposes (Unified Soil Classification System). ASTM, 11.

47. Rodríguez Ortiz, J.M. (1975) Las arcillas expansivas: su estudio y tratamiento. Boletín de Información del Laboratorio del Transporte y Mecánica del Suelo, $n^{\circ}$ 108, 3-30. Madrid.

48. UNE EN 12504-1 (2009) Ensayos de hormigón en estructuras. Parte 1: Testigos. Extracción, examen y ensayo a compresión. AENOR, 14 